\title{
Short-term desalination of Pulicat lagoon (Southeast India) due to the 2015 extreme flood event: insights from Land-Ocean Interactions in Coastal Zone (LOICZ) models
}

\author{
Harini Santhanam ${ }^{1 *}$ (D) and Thulasiraman Natarajan ${ }^{2}$
}

\begin{abstract}
Introduction: We investigated the magnitude and duration of desalination of Pulicat-a coastal lagoon ecosystem connected to the Bay of Bengal on the South-eastern coast of India_during the 2015 South India flood event which was a period of high-magnitude precipitation and riverine flooding.

Methods: We estimated freshwater runoff into the lagoon using flow accumulation models for a period of 55 days (November 1 to December 25, 2015) using daily gridded precipitation data from the Global Precipitation Measurement and a digital elevation model. Using the estimates of freshwater runoff, direct precipitation and observed salinities, we simulated water and salinity fluxes of the lagoon using the Land-Ocean Interactions in the Coastal Zone model. Further, we also used Monte Carlo simulation to estimate the uncertainty in system salinity, the residual salinity at the boundary and the freshwater residence times in the lagoon.

Results: We estimated that a high volume $\left(\sim 760 \times 10^{6} \mathrm{~m}^{3}\right)$ of relatively low salinity waters (residual salinity $\left.=23.47 \mathrm{psu}\right)$ had been exported from the lagoon to the Bay of Bengal during the period which is likely to have caused a strong dip in the daily salinity profile of the coastal sea. We contend that the lagoon experienced $\sim 40 \%$ desalination due to the 2015 event with a freshwater residence time of 18.5 days.

Conclusions: The study highlighted the short-term, high-magnitude desalination undergone by Pulicat lagoon during the 2015 South India floods. Considering the high residual and exchange volumes obtained from the study, we conclude that Pulicat could be a major exporter of relatively low salinity waters to the Bay of Bengal during monsoons.
\end{abstract}

Keywords: Pulicat lagoon, 2015 South India floods, LOICZ model, Flow accumulation model, Bay of Bengal

\section{Introduction}

Shifts in the salinity regimes in coastal lagoon systems from brackish water to freshwater or marine salinities are known to be seasonally progressive; however, such shifts can also occur at variable rates and spatio-temporal scales that could go unnoticed. Normal salinity shifts coincide with the inter-seasonal transitions (from dry to wet or from post-monsoon to pre-monsoon months). A strong regime shift is known to occur between 6 and $8 \%$ salinity in coastal lagoons (Jeppesen et al. 2007). However, highimpact extreme events such as freshwater floods, tsunami

\footnotetext{
* Correspondence: harinis@iisc.ac.in; ecoharini@gmail.com

'Department of Civil Engineering, Indian Institute of Science, Bengaluru, India Full list of author information is available at the end of the article
}

inundation, super cyclones, excessive droughts or acute stresses from pollution can directly impact the ambient salinities and ecosystem statuses within short temporal frames which may not be readily evident from time series data of the variables alone (Scheffer et al. 2001). Moreover, salinity shifts become very significant in shallow and/or intermittently closed or open systems of low ambient salinity and increasing salinities during dry periods (e.g. Debenay et al. 1998 and Jeppesen et al. 2007). The coastal sea accounts for about $12 \%$ of the world's surface (Crossland et al. 2005) and represents a region of strong salinity and nutrient gradients along the river-sea continuum. Fluxes of salinity and dissolved nutrients contribute critical information to the study of changes to 
coastal ecological processes. The export of nutrients from coastal ecosystems can exceed local riverine fluxes across the river-sea continuum (e.g. Dittmar and Lara 2001) leading to changes in the biological carbon pump; alternatively, abrupt desalination by flooding rivers can reverse the scenario making the coastal ocean autotrophic or heterotrophic (e.g. Kempe and Pelger 1991).

Salinity and nutrient budgets of the Bay of Bengal (BoB) show that the system alternates as a net source or sink in tandem with the regional climate variations (e.g. Mukhopadhyay et al. 2002). These changes to the fluxes of salt and nutrients are further constrained by the divisory contributions of large coastal systems at the boundary (e.g. Bonthu et al. 2016 and Prasad et al. 2016) which are seldom accounted for. Thus, water and salinity budgets across the lagoonsea boundary can portend changes to the source-sink characteristics of the BoB at large. The fact that estuarine systems demonstrate highly complex responses and spatio-temporal variability especially in relation to salinity and depth (e.g. Ysebaert et al. 2003) makes it important to record the changes that coastal systems exhibit in response to monsoonal flooding events. Regional estimates of sea surface salinities of the BoB have indicated high-magnitude decreases in salinities during monsoons (e.g. Akhil et al. 2014); however, contributions from large coastal systems can provide valuable insights at finer resolutions. More recently, Behara and Vinayachandran (2016) highlighted the greater influence of monsoonal riverine runoff on lowering the salinity of $\mathrm{BoB}(\sim>2 \mathrm{ppt})$ at the coastal boundary. Although riverine runoff in larger river basins, such as the Ganges-Brahmaputra, is given greater attention, it is also important to understand the relative influence of large brackish water systems along the east coast of India (e.g. Chilika lake and Pulicat lagoon). Sudden changes from high to low salinities are known to adversely impact the macrophyte communities to a large extent (e.g. Charpentier et al. 2005) as well as shrimp populations (e.g. Gelin et al. 2001). While extensive monsoonal dilution of lagoons is relatively commonplace, detailed understanding of the impacts of high-magnitude flooding remains quite critical in deciding whether such events would impact salinity and its regime shifts (e.g. Jeppesen et al. 2007).

Van Oldenborgh et al. (2016) indicated that the December 1, 2015, Chennai rain event, a part of the 2015 South India floods, could be considered an extreme event, given that the region's highest mean precipitation was recorded on that date. In this study, we investigated the responses of Pulicat lagoon (Fig. 1), Chennai's 'backyard' brackish water system and India's second largest lagoon system to this event. Our hypothesis was that the response to this event represented a period of very rapid salinity reversals in a post-event scenario

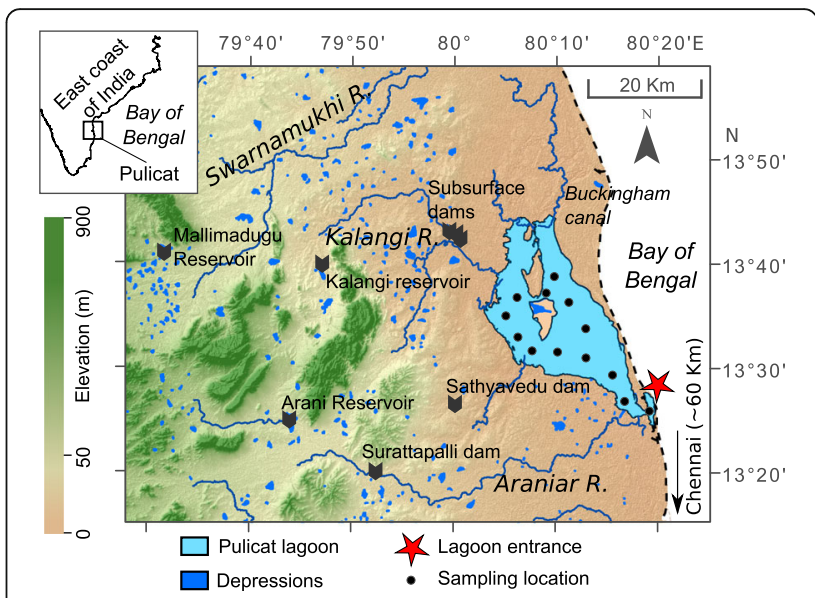

Fig. 1 Pulicat lagoon (filled with cyan) is shown with regional topography derived using CARTOSAT DEM and the major water bodies (marked in blue) of the drainage basin. The river channels (Araniar, Kalangi and Swarnamukhi) are indicated with blue lines. Major dams are marked with black pointers (from Raju et al. 2006, Raju et al. 2013, Sprenger et al. 2015). Entrance of the lagoon into the Bay of Bengal is presently active only near the southern region of the lagoon (marked with a red star). The sampling locations used in the present study for surface salinity are denoted by black dots

corresponding to the period of maximum riverine runoff into the ecosystem, as well as maximum export to the sea (BoB). We attempted to understand and constrain the magnitude and extent of desalination undergone by the ecosystem for providing a holistic picture of the monsoonal salinity changes in 2015 by using runoff estimates from a hydrological flow accumulation model and conservative water and salinity fluxes using the Land-Ocean Interactions in the Coastal Zone (LOICZ) model (an International Geosphere-Biosphere Programme, Gordon Jr. et al. 1996).

\section{Methods}

Study area

Pulicat lagoon system (Fig. 1) is a shallow (area $=\sim 300 \mathrm{~km}^{2}$, average depth $=\sim 1 \mathrm{~m}$; source: GLDB, Kourzeneva et al. 2012), microtidal, endorheic brackish water ecosystem connected to the $\mathrm{BoB}$ on the east coast of India which comprises of the lake water body, the fringe marshes and the islands. The ecosystem belongs to the East India Coastal Province (Longhurst code: INDE), under the Longhurst Biogeographical Provinces classification system (Longhurst 2007, VLIZ 2009). The major part of the lagoon has no direct connection to the sea; active exchange occurs through an entrance in the southern portion of the lagoon near Pulicat town. Monsoonal flows in the rivers Araniar and Kalangi of the western shores in the southern and northern parts of the lagoon, respectively, bring freshwater during the Northeast monsoonal season between October and December causing dilution (Rao and Rao 1974, Raman et al. 1977). The influx of freshwater is often countered by the tidal influx but 
restricted to the southern portion to a distance of about $10 \mathrm{~km}$ from the entrance to the sea (e.g. Raman et al. 1977). Closures of the entrance and low monsoonal precipitation over the years are often cited as factors impacting the salinity characteristics of the lagoon (Coulthard 2008). Sandy shoals emerge in the shallow, central portions during the premonsoon dry seasons. Over the past $70-80$ years, shrinkage of the lagoon has also been reported (e.g. Ramasamy 2006). Several studies across the years provide a comprehensive understanding of the multi-environmental nature of the lagoon (e.g. Kaliyamurthy 1974, Radhakrishnan 1975, Ramesh et al. 2002, Shalini et al. 2006, Purvaja et al. 2008, Reddy et al. 2012 and Jayakumar et al. 2013). The two major fish landing centres at Pulicat and Arambakkam that contribute significantly to the socioeconomics of the region are located on the western shores of this lagoon, which is vulnerable to sudden salinity shifts. The magnitude of precipitation and low salinity are known to impact the fish, oysters (Crassostrea madrasensis), shrimps and prawn (especially the native tiger prawns) populations at Pulicat lagoon (Sanjeevaraj 2006, 2011; Coulthard 2008).

Known to be in the 'eye of the storm' for its proximity to Nellore and Chennai coasts, Pulicat has a long history of flooding due to storm-induced precipitation (e.g. Winckworth 1931). Floods in the rivers Araniar and Kalangi would normally impact the lagoon salinities directly through monsoonal dilution, while freshwater from the river Swarnamukhi could contribute through the sub-surface flows (Raju et al. 2006). However, the upstream dams, reservoirs and 'anicuts' (a local term for check dams) on these rivers (Fig. 1, Sprenger et al. 2015) and managed aquifer recharge structures (Raju et al. 2013, Sprenger et al. 2015) built to divert/store the runoff from monsoons significantly reduce the surface runoff into the lagoon at various points on the western shore. As a result, there have been few possibilities for monsoonal desalination of the lagoon in the recent times (i.e., from 1960s when the first check dams across the rivers came into existence, source: http://www.indiawris.nrsc.gov.in/wrpinfo/index.php?title=Main_Page) under normal conditions. During the 2015 precipitation event, the connecting channels of the Araniar in the south and Kalangi in the north carried the surplus runoff from these reservoirs also into the lagoon, an unusual occurrence. Thus, the flood scenario of November-December, 2015, provided a unique opportunity to study changes to the water and salinity budgets across the river-lagoon-sea continuum during the highest magnitude period of desalination in the recent times.

\section{Precipitation data}

Precipitation for the Pulicat lagoon watershed was obtained from Global Precipitation Measurement (GPM) Level 3 IMERG daily precipitation datasets with a spatial resolution of $10 \times 10 \mathrm{~km}$ for the period November 1-December 31, 2015. The datasets were provided by NASA Goddard Earth Sciences (GES) Data and Information Services Center (DISC). Values in each grid represented the estimates of the daily accumulated precipitation. For example, Fig. 2a, b illustrates the distribution of precipitation on November 23, 2015, and December 1, 2015, respectively. Point observations of rainfall data from the Indian Meteorological Department (Kaur and Purohit 2016) were available for Chennai and Tiruvallur districts (located closer to Pulicat lagoon). We compared them with the GPM IMERGE dataset for ascertaining the ranges of precipitation. Figure 3 presents the temporal distribution of peak precipitation around the Pulicat region. Significant monsoonal precipitation was observed from November 1, 2015, and the peak precipitation for the Pulicat watershed occurred on November 15, 2015 (291 mm), and December 1, 2015 (310 mm). Following December 4 , the intensity of the monsoonal precipitation declined considerably and became very insignificant beyond December 25, 2015 (0.35 mm). Hence, we considered the data between November 1 and December 25, 2015, for the flow accumulation analysis.

\section{Hydrological flow accumulation model}

We used the $\mathrm{A}^{\mathrm{T}}$ (least cost) search algorithm for watershed modelling (Ehlschlaeger 1989) to estimate the flow accumulation of Pulicat drainage basin. This method provided a rapid and accurate procedure to measure the flow accumulation using the precipitation accrued by the topography of the basin derived from Digital Elevation Model (DEM). We obtained a 30-m resolution DEM and depression features (e.g. dams and reservoirs) for the region derived from CARTOSAT data (BHUVAN, ISRO CARTOSAT DEM, 2016) and used a computational resolution of $100 \mathrm{~m}$ by $100 \mathrm{~m}$ grids. Thus, we smoothed the data using bilinear resampling into $100 \mathrm{~m}$ resolution in order to determine the major stream flows. The precipitation layers were resampled similarly. We used the GRASS GIS environment to perform the flow accumulation analysis. Initially, the topographical parameters for the basin were derived from the DEM and depression layer. We then derived the stream flow for each day by adding daily precipitation over the basin configuration and calculated the accumulated runoff values by adding the cumulative flow into the lagoon at the major streams. Figure 2 shows examples of the analysis for two different scenarios. Next, we fed the cumulative flow accumulation values to the LOICZ model as the values of runoff from the event (Fig. 3). Another component of freshwater input into the lagoon was from the direct precipitation, which we computed as the product of the surface area of the lagoon and the daily average precipitation over the lagoon. 


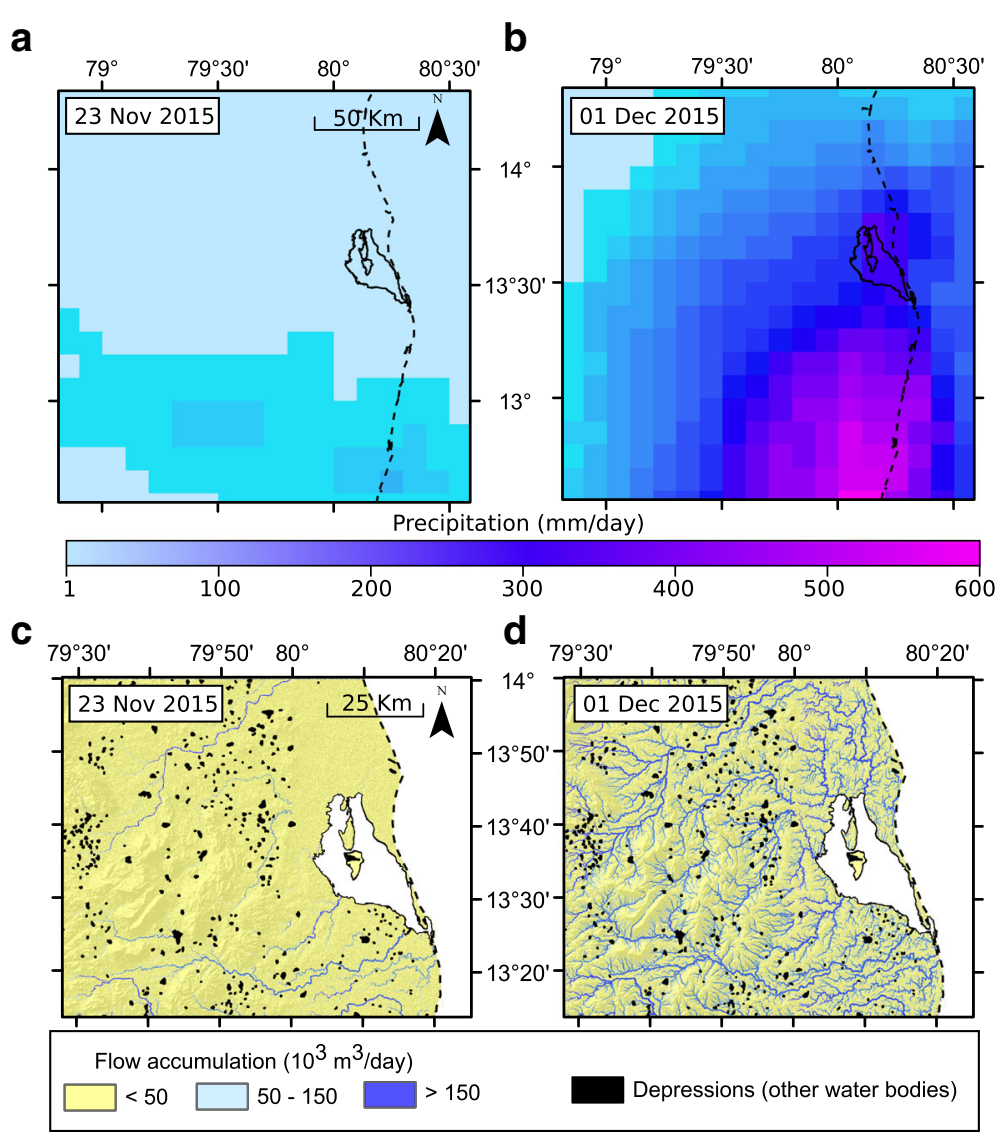

Fig. 2 Example scenarios of precipitation ( $(\mathbf{a}$ and $\mathbf{b}$ ) and the modelled flow accumulation (c and $\mathbf{d}$ ) over Pulicat watershed are shown for 2 days representing a typical monsoon day (November 23, 2015) and the day of peak rainfall (December 1, 2015) respectively

\section{Salinity}

We carried out in situ surface salinity observations at 30 locations from which we selected 12 representative sites distributed within the Pulicat lagoon with an accuracy of \pm 0.1 psu using field probes (make: Thermo Scientific Orion field probes); observations were made during December 25-27, 2015, after the cessation of the rains. The extreme flood situation and related socio-economic

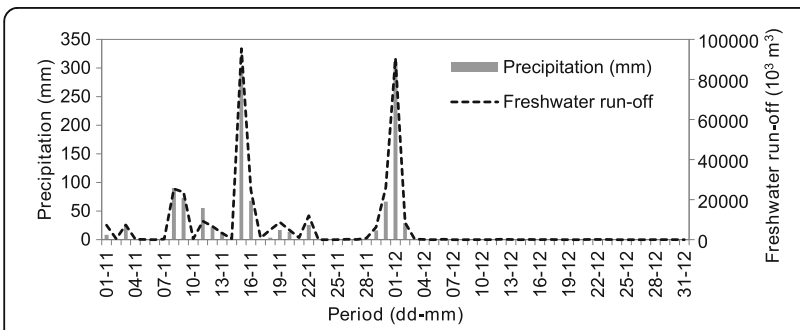

Fig. 3 Graph illustrating the amounts of daily precipitation and freshwater runoff at Pulicat drainage basin from the northeast monsoonal rainfall that caused the 2015 South India floods in November-December, 2015. Note that Pulicat experienced two peak events of precipitation and runoff on 15th November 2015 and 1st December 2015 conditions across the Chennai and Nellore regions starting from the last week of October to the third week of December prevented a continuous in situ monitoring programme during the floods. We consider that our salinity measurements at the end of the monsoon would reflect maximum extent of desalination of the lagoon during the monsoon period. We averaged the observed values to obtain a representative system salinity due the event to be used for the LOICZ modelling. For the purpose of comparison, we compiled the available salinity observations from the past pre-monsoon periods for the years 1997 (Padma and Periakali 1999), 1999 (Institute of Ocean Management AUC 2003), 2005 and 2006 (Santhanam 2009), 2007 (Reddy et al. 2012) and 2015 (present investigation). We derived spatial interpolation plots for six datasets of post-monsoon salinities with observations at different sites within the lagoon, for the years 1997, 1999, 2005, 2006, 2007 and 2015 using the spline interpolation algorithm of Brovelli et al. (2002) in GRASS GIS environment (Fig. 4). These analyses were used to describe the extents of monsoonal desalination over these years.

We obtained the salinity of BoB after spatial-averaging of the daily-scale salinity data from active Argo floats in 


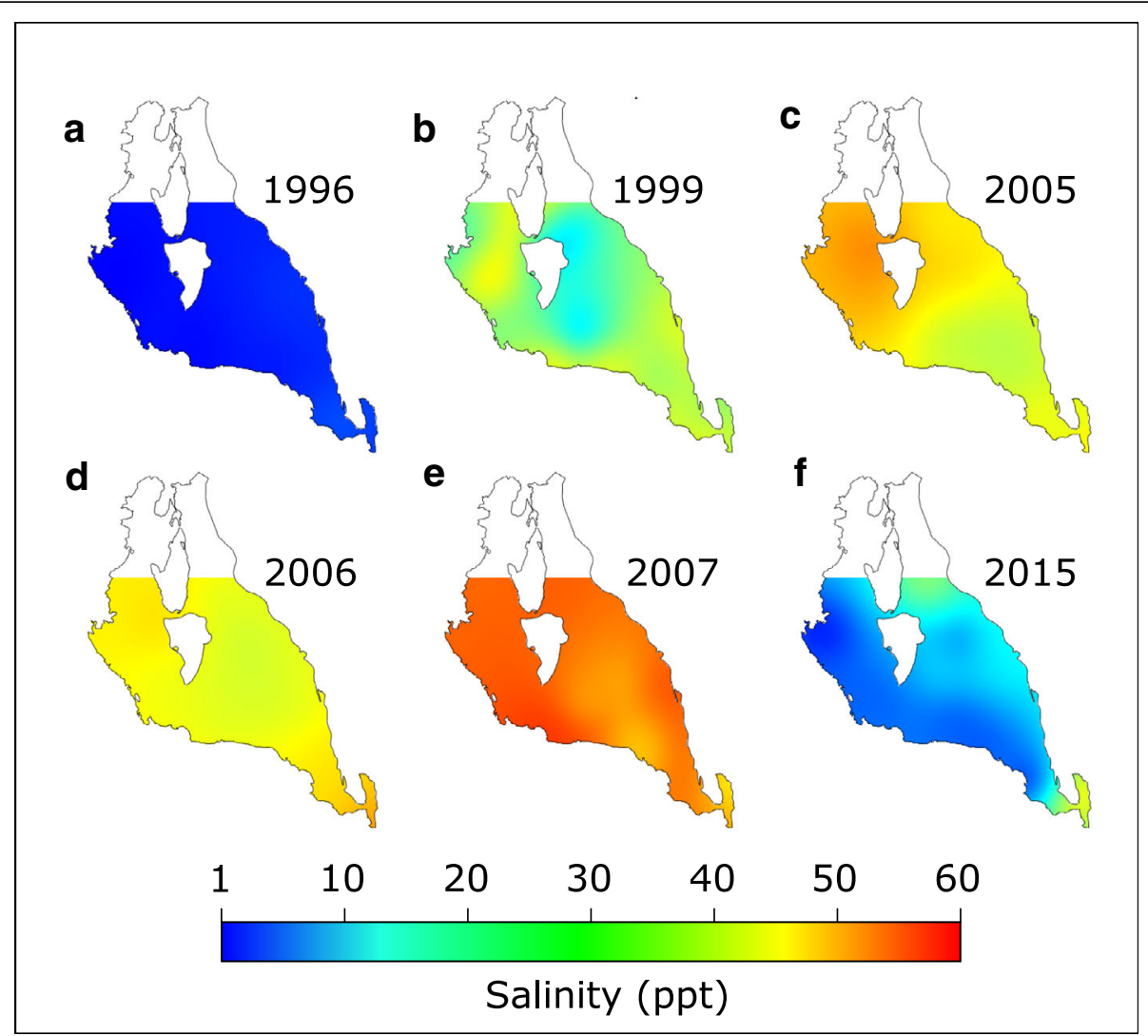

Fig. 4 Spatial models of post-monsoonal surface salinity distribution of Pulicat lagoon for multiple years obtained by interpolating the available data from different locations within the lagoon. Sources for these temporal datasets are (a) Padma and Periakali (1999); (b) IOM, No Impact Zone Studies 2003; (c) and (d) Harini Santhanam 2009; (e) Reddy et al. 2012 and (f) from the present investigation, The years 1996 (a) and 2015 (f) represent periods of highest dilution due to the northeast monsoonal rainfall, with noticeably higher persistence of the freshwater conditions in 1996 than 2015. Low dilution in salinities occurred in the period 2005-2007

the sea close to the coast. These data were collected and made freely available by the International Argo Program and the national programmes that contribute to it (http://www.argo.ucsd.edu, http://argo.jcommops.org; https://doi.org/10.17882/42182\#42348 and https:// doi.org/10.17882/42182\#42344). The Argo Program is part of the Global Ocean Observing System. Salinity data from floats were accessed through the software 'Argo Data and Products for Indian Ocean' of the Indian National Centre for Ocean Information Services, Hyderabad, India; this complemented the global datasets for the period November-December 2015 (Geetha et al. 2011). It is important to note that considering the dynamic location of the floats and their float cycles, data were chosen from the locations closest in distance to the lagoon and closest in date to the flood events to obtain the sea surface salinity for modelling. The salinity profile of $\mathrm{BoB}$ for the whole period is shown in Fig. 5.

\section{The LOICZ model}

We used one-dimensional LOICZ-budget approach to estimate the conservative water and salinity exchanges following the modelling guidelines described in Gordon Jr. et al. (1996) for the period of maximum precipitation and floods at Pulicat between November and December 2015 i.e., 55 days (Fig. 6). The values and units of the different modelling parameters used in the study are provided in Table 1. For the model, we determined the system average water extent to be about $312 \mathrm{~km}^{2}$ and an average depth of $1.6 \mathrm{~m}$ (from direct observations). The water spread area was extracted from a Landsat satellite image of 2015 (NASA Landsat Program 2015). The evaporative outflow $\left(V_{\mathrm{E}}\right)$ during the period was negligible due to the high humidity experienced during the event (Mishra 2016). Based on aquifer characteristics and management in the region (described in detail in Raju et al. 2013 and Sprenger et al. 2015), we also considered the contribution from groundwater flow $\left(V_{\mathrm{G}}\right)$ and hence the contribution of the salinity of groundwater $\left(S_{\mathrm{G}}\right)$ during the period as insignificant compared to the surface flow which was apparently higher during the floods. Maximum freshwater flow $\left(V_{\mathrm{Q}}\right)$ was obtained from the flow accumulation procedure described above. We used the average salinities of the riverine water $\left(S_{\mathrm{Q}}\right)$ 


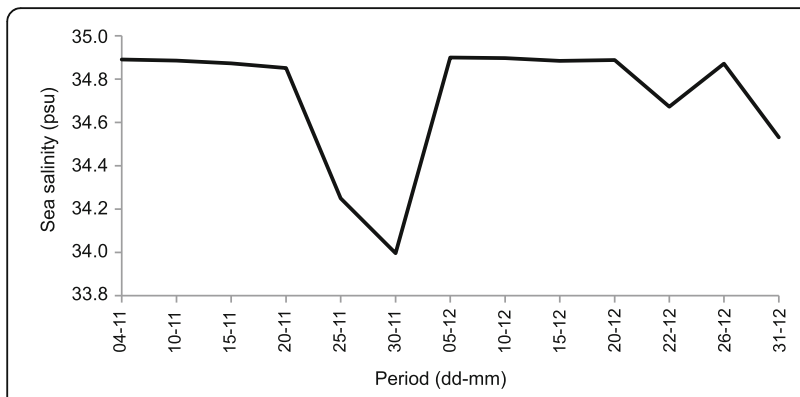

Fig. 5 Surface salinity profile of Bay of Bengal from November 4 to December 31, 2015, obtained from Argo float data. Note that the maximum decline in salinity ( 1 psu) occurred on November 30, 2015, just preceding the peak flow accumulation on December 1 , 2015, when low-saline waters are likely to have been exported from the coastal region including the residual flow from Pulicat lagoon

at both Araniar and Kalangi station to represent the mean salinity of the riverine discharges. Values of the average system salinity $\left(S_{\text {sys }}\right)$ and the average salinity of the ocean $\left(S_{\mathrm{OCN}}\right)$ were used in the LOICZ model for deriving the budgets. We also considered the salinity of contributions of the other stream flows $\left(S_{\mathrm{P}}\right.$ and $\left.S_{\mathrm{o}}\right)$ which can contribute to the salinity of the system to be insignificant. Our assumptions are based on the following considerations following LOICZ guidelines (Gordon Jr. et al. 1996):

1. The salinity of precipitation (i.e. $\mathrm{S}_{\mathrm{P}}$ ) may be assumed to be nil or insignificant to contribute to an increase in the overall salinity,

2. Other stream flows $\left(V_{\mathrm{O}}\right)$ calculated using our hydrological model provided very low values for the flow accumulation which did not significantly contribute to the overall flow accumulation. Hence, we considered that the salinity of these flows would also insignificantly contribute to the increase in the overall system salinity.

We briefly describe here the procedure for deriving the water and salinity budgets as per Gordon Jr. et al. (1996). The residual water volume $\left(V_{\mathrm{R}}\right)$ at steady state conditions is calculated as the difference of the sum of the input sources of water from various sources (freshwater discharge, precipitation, groundwater seepage and other

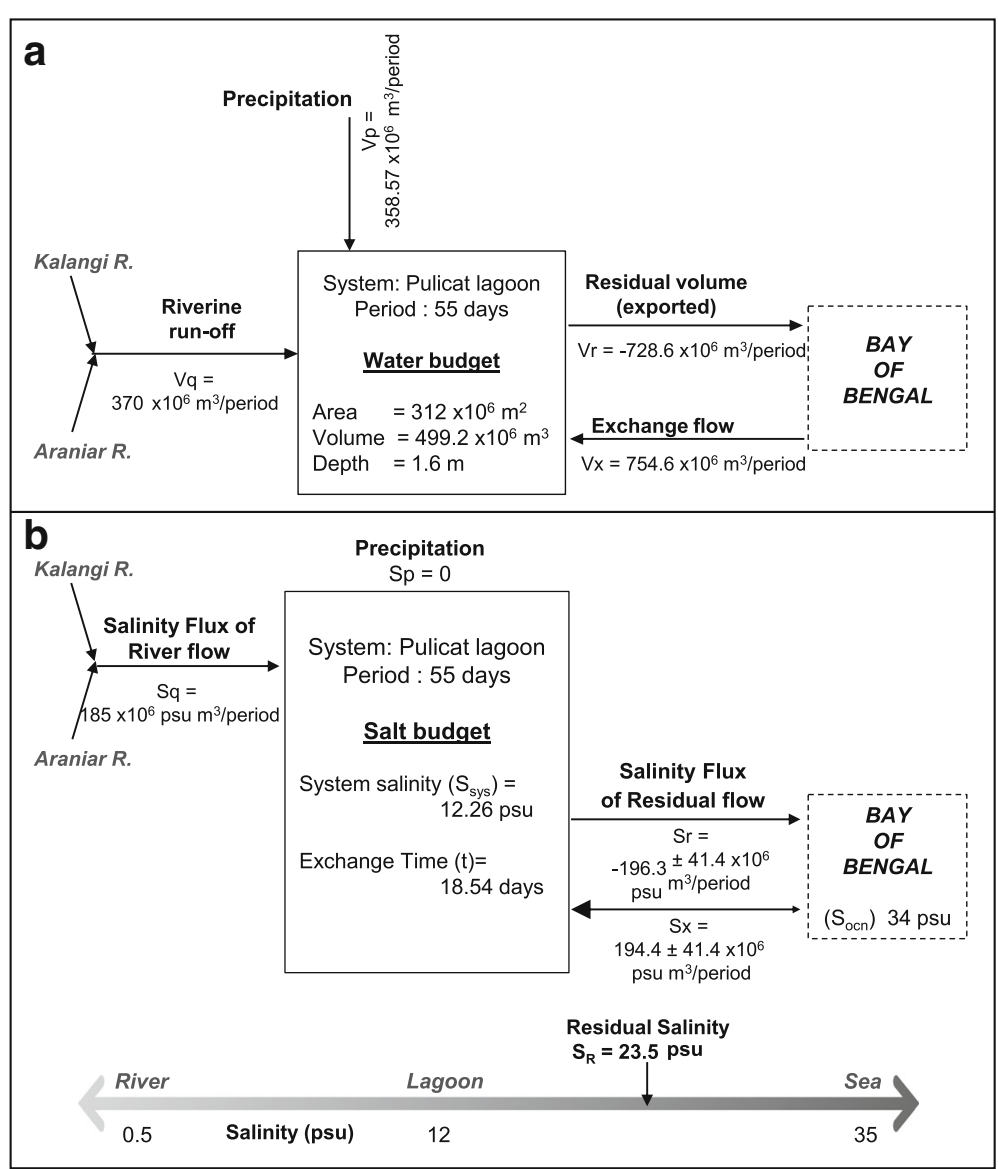

Fig. 6 LOICZ budgets for Pulicat lagoon during a period of 55 days corresponding to the northeast monsoonal rainfall of 2015. a shows the water fluxes and $\mathbf{b}$ shows the salinity budgets 
Table 1 The variables used in the construction of LOICZ budget as per the modelling guidelines detailed in Gordon Jr. et al. (1996)

\begin{tabular}{lllll}
\hline Parameter & Definition & Units & Model inputs & Source \\
\hline$A$ & Surface area of the lagoon & $10^{6} \mathrm{~m}^{2}$ & 312 & Landsat imagery survey \\
$D$ & Depth of the lagoon & $\mathrm{m}$ & 1.6 & Direct field measurements \\
$V$ & Volume of the lagoon & $10^{6} \mathrm{~m}^{3}$ & 499.2 & Calculation using area and depth \\
$V_{\mathrm{P}}$ & Precipitation volume & $10^{6} \mathrm{~m}^{3}$ period $^{-1}$ & $358.57 \pm 0.0012$ & $\begin{array}{l}\text { GPM Level } 3 \text { IMERG Final Daily } 10 \times 10 \mathrm{~km} \\
\text { from the half-hourly GPM_3IMERGHH data }\end{array}$ \\
$V_{\mathrm{Q}}$ & Riverine runoff flow volume & $10^{6} \mathrm{~m}^{3}$ period $^{-1}$ & $370 \pm 0.0012$ & Obtained from flow accumulation model \\
$S_{\text {sys }}$ & Mean system salinity of Pulicat & $\mathrm{psu}$ & $12.265 \pm 0.1$ & Direct field measurements \\
$S_{\mathrm{OCN}}$ & Mean system salinity of Bay of Bengal & $\mathrm{psu}$ & $34 \pm 0.29$ & Argo float data from International Argo \\
& & & & Program and Argo Data Products for Indian \\
$S_{\mathrm{Q}}$ & Salinity of riverine runoff & $\mathrm{psu}$ & $0.5 \pm 0.1$ & Ocean (Geetha et al. 2011)
\end{tabular}

discharges) and the sum of the outputs (evaporation and exchange with the sea) required to balance the water budget of the lagoon ecosystem. The changes to the system volume and the residual flow are calculated as the water budget which we provide in Eqs. 3.1 and 3.2 below:

$$
\frac{d V \text { sys }}{d t}=V_{\mathrm{Q}}+V_{\mathrm{P}}+V_{\mathrm{G}}+V_{\mathrm{O}}+V_{\mathrm{E}}+V_{\mathrm{R}}
$$

where,

$V_{\text {sys }}=$ the system volume,

$V_{\mathrm{Q}}=$ inflows from stream runoff,

$V_{\mathrm{P}}=$ flow due to direct precipitation,

$V_{\mathrm{G}}=$ groundwater flow,

$V_{\mathrm{O}}=$ other inflows such as sewage,

$V_{\mathrm{E}}=$ evaporation and

$V_{\mathrm{R}}=$ residual flow.

Residual volume $\left(V_{\mathrm{R}}\right)$ is the difference between $V_{\text {in }}$ and $V_{\text {out }}\left(V_{\mathrm{R}}=V_{\text {in }}-V_{\text {out }}\right)$ and assuming that $d V_{\text {sys }} / d t=0$ :

$$
V_{\mathrm{R}}=V_{\text {in }}-V_{\text {out }}=-V_{\mathrm{Q}}-V_{\mathrm{P}}-V_{\mathrm{G}}-V_{\mathrm{O}}-V_{\mathrm{E}}
$$

A negative value of $V_{\mathrm{R}}$ indicates that there is a net outflow from the lagoon system to the $\mathrm{BoB}$, and a positive value of $V_{\mathrm{R}}$ implies a net inflow from the sea. ' $S_{\text {sys }}$ ' represents the spatially averaged system salinity and ' $S_{\mathrm{OCN}}$ ' represents the salinity of BoB. The residual salinity $\left(S_{R}\right)$ at steady state conditions is calculated as the average of the salinities of the lagoon and the sea. Exchange flow or mixing flux $V_{\mathrm{X}}$ was calculated as shown in Eq. 3.3:

$$
V_{\mathrm{x}}=\frac{\left(V_{\mathrm{Q}} S_{\mathrm{Q}}+V_{\mathrm{P}} S_{\mathrm{P}}+V_{\mathrm{G}} S_{\mathrm{G}}+V_{\mathrm{O}} S_{\mathrm{O}}+V_{\mathrm{R}} S_{\mathrm{R}}\right)}{\left(S_{\mathrm{ocn}}-S_{\text {sys }}\right)}
$$

where,

$S_{\text {sys }}=$ system salinity of Pulicat

$S_{\mathrm{ocn}}=$ salinity of $\mathrm{BoB}$
$S_{\mathrm{Q}}=$ salinity in stream runoff

$S_{\mathrm{P}}=$ salinity due to direct precipitation

$S_{\mathrm{G}}=$ salinity of groundwater

$S_{\mathrm{O}}=$ salinity of other inflows such as sewage

The ratio of the absolute value of the system volume to the residual flow i.e., $\tau$, with units of days, provided the 'freshwater residence time' or the 'hydraulic residence time' of the system. Exchange time or the freshwater residence time $(\tau)$ was calculated as the system volume divided by the sum of absolute value of residual flow and exchange flow shown in Eq. 3.4:

$$
\tau=\frac{V_{\text {sys }}}{\left|V_{\mathrm{R}}\right|+\left|V_{\mathrm{X}}\right|}
$$

These two estimates were important to constrain the extent of the desalination of the system. $\tau$, which is the average residence time for which the solutes remained in the system, indicated the period for which the lowsalinity water from precipitation remained in the lagoon before the eventual exchange with the sea happened.

We used the spreadsheet model, LOICZ Toolbox application and guidelines provided in Swaney and Hong (2009a) to construct the budget models and to perform the uncertainty and sensitivity analyses. Such simple spreadsheet models have been highly recommended for their ease and efficiency in deriving estimates of water, salinity and nutrient budgets for coastal systems (Ramesh et al. 2015). The sensitivity of the input parameters for the model directly indicates their close relationships with the model outputs such as the residual flux, exchange volume, residual salinity and residence time (Gordon Jr. et al. 1996).

Uncertainty and sensitivity analyses, maximum likelihood estimation

Changes to the ecosystem during the above-mentioned period of 55 days are expected to be dynamic including 
the changes to the salinity profiles of the lagoon and the sea. Under the extreme conditions of the region's historic and unmitigated flood, it was not possible to obtain direct estimates for model input parameters such as salinity until December 25, 2015. We consider this date as the temporal limit for maximum desalination of the lagoon based on the absence of precipitation. However, the spatial analysis of the post-monsoonal changes of salinity of the lagoon for a decadal scale provided the closest estimates and the ranges of the mean monsoon lagoon salinity. Given these circumstances, uncertainty and sensitivity analyses were deemed necessary to assess the impact of different perturbation rates for the system.

First, we performed a standard Monte Carlo uncertainty analysis (Fig. 7) considering averages and standard deviations (S.D.) for the input parameters listed in Table 1. This analysis consists of a sequence of operations for deriving probability distributions for a selected set of model parameters and repeating the simulation of each realisations of the parameter set (Swaney and Hong 2009b). We generated 100 such realisations of each of these parameters and also calculated the resulting means as well as S.D. of the model variables over all such realisations of the given parameter set. Stochastic values were generated by this uncertainty model and we simulated the changes in the values of $S_{\mathrm{R}}$ and $\tau$ corresponding to the changes in the values of $S_{\text {sys }}$ and $S_{\text {ocn, while }}$ keeping the following parameters constant: $A, V, D, V_{\mathrm{p}}$, $V_{\mathrm{Q}}$ and $S_{\mathrm{Q}}$. As per the LOICZ modelling guidelines (Gordon Jr. et al. 1996), we assumed that these parameters remained conservative during the period of investigation for assessing uncertainties in the distribution of the $S_{\mathrm{sys}}, S_{\mathrm{ocn}}, S_{\mathrm{R}}$ and $\tau$. The best estimates of $S_{\mathrm{R}}$ and $\tau$ from the model were obtained. We derived gamma distributions for all parameter sets assuming a mean monsoonal salinity $\left(S_{\text {sys }}\right)$ of $20 \pm 10$ psu and a mean sea salinity $\left(S_{\text {ocn }}\right)$ of $34 \pm 3$ psu.

We also performed a series of sensitivity analyses (Fig. 8) to simulate the changes of critical parameters
$S_{\text {sys }}, S_{\text {ocn }}, S_{\mathrm{R}}$ and $\tau$ if the baselines values decreased or increased by $1,5,10,15,20,25,30,35,40,45,50,75$, 80,90 and $100 \%$. The aim was to derive the minimum and maximum likelihoods as well as the best estimates for a range of perturbation levels to the system. This analyses thus measured the extent of changes to all the model parameters when a respective percentage of change is applied from the given baseline salinity values. For example, a $1 \%$ change on a salinity of 20 psu (baseline) would mean a shift by $\pm 1 \%$ from this value resulting in changes to all calculated variables from their respective baselines. We considered that changes greater than $50 \%$ were not very likely and that a $100 \%$ change would be impossible to be realised. Thus, we modelled perturbation as the magnitude of the desalination under the various levels of the changes to all the model parameters. In the absence of direct estimates of the values encountered at different perturbation scenarios, this model provided us the opportunity to simulate the best possible scenarios (values) that would reflect the actual field measurements of salinity. Using our measurements of salinity on the 25th December to validate all these scenarios, we arrived at the most probable estimates of the variables which could have facilitated a drop in the salinity to $12.26 \mathrm{psu}$.

\section{Results and discussion}

\section{Spatial salinity distributions of Pulicat lagoon}

Spatial interpolation of the salinities showed temporal variations in the salinities; the mean salinity of the lagoon was on the order of $20 \pm 10$ psu across the years 1996-2007 (Fig. 4(a-f)). We observed that the combined influence of the precipitation and riverine flows in the monsoon period of 2015 had transformed the lagoon system to a freshwater-dominated system (Fig. 4(f)). In the years leading to the major desalination event in 2015, the marine dominance of the lagoon had been attributed to failure of monsoons and the insignificance of the riverine inputs which play an important role in


Fig. 7 The values of the system salinity (Pulicat lagoon) as well as the sea salinity (Bay of Bengal) obtained as 100 realisations of the variables using Monte-Carlo simulations derived using the budget tool developed by Swaney and Hong (2009b). a Gamma distributions of the modelled salinities between the two exchanging systems and the corresponding changes in the freshwater residence times within Pulicat system. b Maximum likelihood estimates and modelled salinities closest to in situ measurements of surface salinities in the lagoon and the sea (outlined points) are shown versus their freshwater residence times 


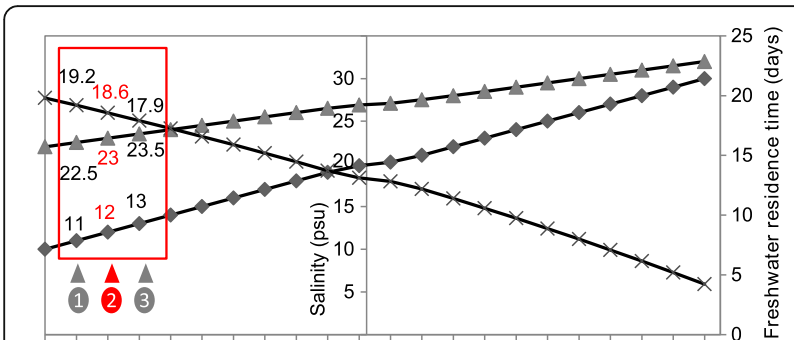

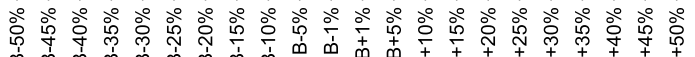
ம. Percent perturbation

$\longrightarrow$ - System salinity $\longrightarrow$-Residual salinity $\rightarrow$ Freshwater residence time

Fig. 8 Sensitivity parameters and models of perturbation i.e., the extent of desalination of Pulicat lagoon corresponding to changes in the system (Pulicat) and sea (Bay of Bengal) salinities as well as the freshwater residence times. The sensitivity models were constructed using the tool developed by Swaney and Hong (2009b)

imparting the brackishness (e.g. Coulthard 2008). An exception is the year 1996 (Fig. 4(a)) which exhibits the highest magnitude of desalination in the recent years in response to the cyclone-induced precipitation in December, 1996. This coincides with the high dilution from riverine sources due to high northeast monsoonal precipitation in this year which is the closest to the 2015 scenario. Beginning with the year 1999, however, we note that the mean post-monsoon salinities have shown an increasing trend over the years up to 2007 (Fig. 4(b-e)).

\section{Water and salinity budgets}

Figure 6 shows the water and salinity budgets obtained from LOICZ model for a period of 55 days between November 1 and December 25, 2015. The total volume of water exported to the $\mathrm{BoB}$ was $728.6 \times 10^{6} \mathrm{~m}^{3}$. This was in response to the extraordinary amount of freshwater influx to the lagoon from direct precipitation $(358.6 \times$ $\left.10^{6} \mathrm{~m}^{3}\right)$ as well as riverine runoff $\left(370 \times 10^{6} \mathrm{~m}^{3}\right)$. Annual estimates of the freshwater residence times ranged between 9 and 74 days and the annual residual flow was estimated to be in the range of $0.8-1.3 \times 10^{6} \mathrm{~m}^{3}$ between 1990 and 2006 for the lagoon (Santhanam and Amalraj 2016). Prasad et al. (2016) reported a residual volume of $137.92 \times 10^{3} \mathrm{~m}^{3}$ day $^{-1}$ for the Pichavaram estuarinemangrove system (located about $275 \mathrm{~km}$ south of Pulicat) which has a surface area of $11 \mathrm{~km}^{2}$ and an average depth of $0.5 \mathrm{~m}$ during the monsoon season. Lesser estimates of the residual volume $\left(3.86 \times 10^{6} \mathrm{~m}^{3}\right.$ day $\left.^{-1}\right)$ have been reported for the monsoon season at Muthupet lagoon $\left(A=13.32 \mathrm{~km}^{2}, V=9.6 \times 10^{6} \mathrm{~m}^{3}\right.$, Gupta et al. 2006). On the other hand, Bonthu et al. (2016) estimated that the monsoonal advective water outflow from Chilika lagoon $\left(A=1165 \mathrm{~km}^{2}, V=1.7 \mathrm{~m}\right)$ to be $\sim 72 \times 10^{9} \mathrm{~m}^{3}$ year $^{-1}$ which is quite high. However, the estimate for a single period of 55 days for Pulicat lagoon seems quite significant compared to the seasonal or annual scale budgets for the lagoon as well as other systems.

The exchange flow from BoB of about $754.6 \times 10^{6} \mathrm{~m}^{3}$ which is based on balancing the outflow of salinity (Fig. 6) is also higher than the actual volume of the lagoon $\left(500 \times 10^{6} \mathrm{~m}^{3}\right)$. This indicates that, while on one hand the flushing of the lagoon with the freshwater seems to have been complete, converting the lagoon temporarily into a freshwater lake, the balancing exchange flow from the sea in return is also observed to be higher and must have reached all portions of the lagoon which is quite unique. Such a dominant freshwater flushing in the recent past occurred in the year 1996 (Fig. 4(a)) due to cyclonic storm-induced precipitation (Padma and Periakali 1999). Under the circumstances, the 2015 event had not only facilitated a significant drop in the average salinity but also lateral well-mixing of the waters within the lagoon.

The salinity budgets obtained from the model (Fig. 6b) show that the mixing flux at the coastal boundary has been quite extensive $\left(\sim 196.3 \times 10^{6} \mathrm{psu} \mathrm{m}^{3}\right)$ and the freshwater residence time (exchange time) was 18.54 days. The higher residence time within the lagoon must have facilitated the complete desalination of the lagoon during the period and is an important result to consider from the perspective of regime shift. Estimates of residence times for other lagoons on the east coast have varied between 1.4 and 4.3 days for Muthupet and Pichavaram (Gupta et al. 2006, Prasad et al. 2016), indicating faster revival of the tidal influx. The freshwater residence time is known to be sensitive to salinity ranges prevalent in the lagoon; higher periods (in months or years) are known to indicate higher riverine influences compared to tidal mixing on the lagoon and vice versa (e.g. Bonthu et al. 2016). The freshwater residence time estimated for the 2015 event indicates that while initially riverine discharges would have facilitated desalination, the tidal influx after $\sim 18.5$ days restored brackishness to the lagoon. This observation coincides well with a sudden drop in the salinity ( $0.6 \mathrm{psu})$ of BoB close to Pulicat shore observed between November 19-20, 2015, from the Argo float data (Fig. 5). The salinity drop ( 1 ppt decrease) was quite pronounced on November 30 , 2015 , corresponding to the peak precipitation and flood event on December 1, 2015. We speculate that the large volume of low-saline waters exported from the Pulicat system between November 19 and 29, 2015, could have contributed towards the drop closer to the coast. It is to be noted that even a decrease of 1 ppt in the sea surface salinity requires to be treated with caution (Behara and Vinayachandran 2016). A lesser decrease of about 0.2 psu at BoB occurred on December 22, 2015, approximately 19-20 days after the first exchange again coinciding with the exchange time for the period. 


\section{Uncertainty model}

Gamma distributions of the freshwater residence times were plotted versus the salinities of Pulicat and the BoB as well as the residual salinities at the boundary (Fig. 7a, b). These provided 100 realisations (stochastic values) of the parameter sets from the uncertainty model. The computed uncertainties in the system salinities seem to be larger with higher standard errors (S.E.) compared to that of $\mathrm{BoB}$ indicating that a wide spectrum of changes is likely to have materialised during the period (Fig. 7a). The range of fluctuations in the freshwater residence times seems to be higher with respect to modelled ranges of the system salinity (with higher S.E.) rather than those of BoB (lower S.E.). These observations suggest that the system salinities are likely to have undergone a higher range of variations between $\sim 4.5$ and 32 psu based on the changes in precipitation and riverine runoff. The model indicated the ranges of salinities of the sea could have varied between $\sim 24.5$ and $42.7 \mathrm{psu}$ in response to the changes in the ranges of the system salinities. These results support our observations on the large decrease in the system salinities and corresponding export of low saline waters to the sea during the 2015 event.

The results also indicate that increase in the system salinity causes a corresponding decline in the residence times. From the modelled values, we selected subsets (Fig. 7b) which were in good agreement with the observed values of the salinities from the field. It would be helpful to recall that we considered the spatial models over different periods in the past to reflect the maximum possible decrease in the salinity of the system from the mean monsoonal salinities of 20 $\pm 10 \mathrm{psu}$ at the end of the 55 days corresponding to the mean sea salinities of $30 \pm 3$ psu. The LOICZ model provided a residual salinity of $\sim 23$ psu and residence time of $\sim 18.5$ days for the current period. Figure 8 shows the three model scenarios (highlighted in the box) reflecting the most probable values of salinities of the system, the sea and the residence times that would have been prevalent during the period. For example, the residual salinity in the range of 2225 psu are observed to be produced when the system salinities are in the range of 12 to 13 psu and sea salinities between 32 and 35 psu for these three realisations. The corresponding residence times were modelled to occur between 18.4 and 18.6 days. The observed (marked as black-bordered points) show good agreement with the actual values of these parameters (system salinity $=12.26 \mathrm{psu}$, the sea salinity $=34.7 \mathrm{psu}$ and the residual salinity $=23.47 \mathrm{psu}$ for the residence time of 18.5 days). Thus, we contend that despite the high amount of uncertainty, the model has well-constrained the most probable ranges of the salinities that could have been prevalent at the period of desalination of the lagoon. Hence, it emerges that the period of highest decrease in the system salinity corresponds to a freshwater residence time of 18.5 days.

\section{Sensitivity model}

We simulated the different perturbation scenarios by assuming different percentages of disturbances ('percent perturbation, Fig. 8) to the system from 1 to $100 \%$. We assumed the same mean salinities for both the system and the sea as baselines for modelling the resultant changes to the residual salinity and residence times. Based on the modelling guidelines detailed in Swaney and Hong (2009a), we considered the following important assumptions to select a set of practically possible scenarios from the simulations that could represent either positive or negative deviations from the baseline values:

1. Significant changes to the salinities would well be detected above $\pm 5 \%$ perturbation levels, although sensitivity to changes less than $5 \%$ of the baseline was also considered.

2. Changes of the order of $\pm 10 \%$ from baselines were significant for considering the extent of change in salinities,

3. Percent perturbations higher than $\pm 50 \%$ (i.e. \pm 60 100\%) are not realistic.

Figure 8 shows the values for salinity and residence times obtained from the sensitivity model. We selected 11 scenarios depicting different degrees of desalination and 11 corresponding scenarios which simulated increase in the salinities in response to the respective perturbation levels (Table 2). This set of 22 scenarios emerged as the probable scenarios for the lagoon amongst the whole range of simulations between \pm 1 to $\pm 100 \%$. We compared the modelled values to system salinities, residual salinity and residence times with our direct observations and estimates from the LOICZ model.

Scenarios 2, 3 and 4 emerged as the cases for which the simulated values were closer to the observed values (Fig. 8). These represented the negative percent perturbations of 35, 40 and 45 from the baseline illustrating that desalination of the order of $35-45 \%$ has occurred in the system due to the 2015 flood event. The scenarios provided a range of system salinities, the residual salinity and the residence times corresponding to the 35,40 and $45 \%$ decrease from baseline salinity as follows: 11, 12 and 13 psu; 22.5, 23 and 23.5 psu; 19.2, 18.6 and 17.9 days, respectively. Of these, scenario 3 represented the best set of estimates and scenarios 2 and 4 represented the closest minimum and maximum likelihoods for the event. 
Table 2 The different model scenarios simulated for the desalination extents ranging between \pm 1 and $50 \%$ from the baseline values ('B') for Pulicat lagoon. * represents the simulated scenario that is closest to the real-time estimates

\begin{tabular}{|c|c|c|c|c|}
\hline Scenario & Perturbation level & $\begin{array}{l}\text { System } \\
\text { salinity (psu) }\end{array}$ & $\begin{array}{l}\text { Residual } \\
\text { salinity (psu) }\end{array}$ & $\begin{array}{l}\text { Freshwater residence } \\
\text { time (days) }\end{array}$ \\
\hline 1 & $B-50 \%$ & 10 & 22 & 19.8 \\
\hline 2 & $B-45 \%$ & 11 & 22.5 & 19.2 \\
\hline 3 & $B-40 \% *$ & 12 & 23 & 18.6 \\
\hline 4 & $B-35 \%$ & 13 & 23.5 & 17.9 \\
\hline 5 & $B-30 \%$ & 14 & 24 & 17.3 \\
\hline 6 & $B-25 \%$ & 15 & 24.5 & 16.6 \\
\hline 7 & $B-20 \%$ & 16 & 25 & 15.9 \\
\hline 8 & $B-15 \%$ & 17 & 25.5 & 15.2 \\
\hline 9 & $B-10 \%$ & 18 & 26 & 14.5 \\
\hline 10 & $B-5 \%$ & 19 & 26.5 & 13.7 \\
\hline 11 & $B-1 \%$ & 19.8 & 26.9 & 13.1 \\
\hline 12 & $B+1 \%$ & 20.2 & 27.1 & 12.8 \\
\hline 13 & $B+5 \%$ & 21 & 27.5 & 12.2 \\
\hline 14 & $B+10 \%$ & 22 & 28 & 11.4 \\
\hline 15 & $B+15 \%$ & 23 & 28.5 & 10.6 \\
\hline 16 & $B+20 \%$ & 24 & 29 & 9.7 \\
\hline 17 & $B+25 \%$ & 25 & 29.5 & 8.9 \\
\hline 18 & $B+30 \%$ & 26 & 30 & 8.0 \\
\hline 19 & $B+35 \%$ & 27 & 30.5 & 7.1 \\
\hline 20 & $B+40 \%$ & 28 & 31 & 6.2 \\
\hline 21 & $B+45 \%$ & 29 & 31.5 & 5.2 \\
\hline 22 & $B+50 \%$ & 30 & 32 & 4.2 \\
\hline
\end{tabular}

It is important to note that the residence times are negatively related to the increase in salinity as the uncertainty model had indicated. Positive increments from the baseline to the percent perturbations lead to decrease in residence times which do not conform with the estimates from the LOICZ model as well as the direct field observations; the positive increases to salinity are hence deemed improbable.

\section{Conclusions}

The present investigation provided an understanding of the magnitude and duration of desalination of Pulicat lagoon under the impact of the large-scale precipitation and riverine runoff between November 1 and December 25, 2015. The period represents a recent dynamic, short-term, high-magnitude desalination of the marine-dominated lagoon. Field investigation revealed that the dilution due to the freshwater discharge into the lagoon lowered salinities drastically and the mean salinity of $12.26 \pm 0.5$ psu was encountered 2 weeks after the peak floods. LOICZ models coupled with uncertainty and sensitivity modelling were useful to constrain the magnitude and duration of the desalination of the lagoon. This approach was useful to simulate the uncertainties in the values of salinities for the entire period and to determine the most probable parameter sets for which the observed values were closer to the modelled values. From the different sensitivity models, one scenario representing the decrease in the salinities by $40 \%$ from baseline values emerged as the best model to depict the extent of desalination from the 2015 event.

The freshwater residence time of 18.5 days conformed with decrease in both residual and sea salinities between November 19 and 30, 2015, which was followed by the second peak flood on December 1, 2015. A salinity reversal from predominantly marine to freshwater must have lasted up to the first week of December, 2015, while slowly decreasing in magnitude towards the third week, thereby reducing carry-over salinity for the subsequent year. The first 2 weeks of high-impact flooding likely resulted in a higher area of freshwater influence over the tidal inflow, with the slow cessation of the rains in the third week of December. Subsequently, the influence of the tidal flow restored the ecosystem to brackish salinity levels. The LOICZ model indicated that a high volume of low saline waters $\left(728.6 \times 10^{6} \mathrm{~m}^{3}\right.$; residual salinity $23 \mathrm{psu}$ ) were exported to the sea within a period of 
55 days. BoB is known for being a low-saline sea owing to export of freshwaters from the large riverine systems such as Ganges-Brahmaputra. We contend that Pulicat could also be a major exporter of low-saline waters to the BoB during the monsoons.

\section{Acknowledgements}

Harini Santhanam (HS) acknowledges the DST Woman Scientist project (2015-18) for field work. The authors thank Professor Dennis Swaney for his help towards improving the language. The authors acknowledge BHUVAN, ISRO for CARTOSAT DEM data, NASA for the GPM precipitation data and open source tools GRASS, QGIS, R and INKSCAPE.

\section{Authors' contributions}

HS and TN participated in the field investigations and data collection. TN collected precipitation and DEM datasets and developed flow accumulation model and spatial maps for representation. HS performed LOICZ budgeting and derived water and salinity fluxes as well as drafted the manuscript. Both authors read, contributed and approved the manuscript submitted.

\section{Competing interests}

The authors declare that they have no competing interests.

\section{Publisher's Note}

Springer Nature remains neutral with regard to jurisdictional claims in published maps and institutional affiliations.

\section{Author details}

${ }^{1}$ Department of Civil Engineering, Indian Institute of Science, Bengaluru, India. ${ }^{2}$ Centre for Earth Sciences, Indian Institute of Science, Bengaluru, India.

Received: 14 November 2017 Accepted: 12 February 2018

Published online: 16 March 2018

\section{References}

Akhil VP, Durand F, Lengaigne M, Vialard J, Keerthi MG, Gopalakrishna W, Deltel C, Papa F, de Boyer Montégut C (2014) A modeling study of the processes of surface salinity seasonal cycle in the Bay of Bengal. J Geophys Res Ocean 119:3926-3947. https://doi.org/10.1002/2013JC009632

Behara A, Vinayachandran PN (2016) An OGCM study of the impact of rain and river water forcing on the Bay of Bengal. J Geophys Res Ocean 121:2425-2446. https://doi.org/10.1002/2015JC011325

BHUVAN, ISRO CARTOSAT DEM. http://bhuvan.nrsc.gov.in. Accessed 24 Jan 2016 Bonthu S, Ganguly D, Ramachandran P, Ramachandran R, Pattnaik AK, Wolanski E (2016) Both riverine detritus and dissolved nutrients drive lagoon fisheries. Estuar Coast Shelf Sci 183:360-369. https://doi.org/10.1016/j.ecss.2016.07.016

Brovelli M, Cannata M, Longoni U (2002) Managing and processing LIDAR data within GRASS. In: Proceedings of the Open Source GIS-GRASS Users Conference 2002 Trento Italy. Italy: University of Trento; pp 1-29

Charpentier A, Grillas P, Lescuyer F et al (2005) Spatio-temporal dynamics of a Zostera noltii dominated community over a period of fluctuating salinity in a shallow lagoon, Southern France. Estuar Coast Shelf Sci 64:307-315. https://doi.org/10.1016/j.ecss.2005.02.024

Coulthard S (2008) Adapting to environmental change in artisanal fisheries_insights from a South Indian Lagoon. Glob Environ Chang 18:479-489. https://doi.org/10.1016/j.gloenvcha.2008.04.003

Crossland CJ, Baird D, Ducrotoy J-P, Lindeboom H (2005) The coastal zone-a domain of global interactions. In: Crossland CJ, Kremer HH, Lindeboom H, et al. (eds) Coastal fluxes in the Anthropocene: the land-ocean interactions in the coastal zone project of the International Geosphere-Biosphere Programme, 219 p. Germany: Springer Science \& Business Media; pp 1-34

Debenay J, Eichler BB, Duleba W, Bonetti C, Eichler-coelho P (1998) Water stratification in coastal lagoons: its influence on foraminiferal assemblages in two Brazilian lagoons. Mar Micropaleontol 35:67-89. https://doi.org/10.1016/ S0377-8398(98)00011-5

Dittmar T, Lara RJ (2001) Do mangroves rather than rivers provide nutrients to coastal environments south of the Amazon River? Evidence from long-term flux measurements. Mar Ecol Prog Ser 213:67-77. https://doi.org/10.3354/meps213067
Ehlschlaeger CR (1989) Using the AT search algorithm to develop hydrologic models from digital elevation data. Proc Int Geogr Inf Syst Symp '89 275-281

Geetha G, Bhaskar TVSU, Rao EPR (2011) Argo data and products of Indian Ocean for low bandwidth users. Int J Ocean Oceanogr 5:1-8 http://www.ripublication. com/Nolume/ijoov5n1.htm

Gelin A, Crivelli A, Rosecchi E, Kerambrun P (2001) Can salinity changes affect reproductive success in the brown shrimp Crangon crangon? Crustac. Biol 21:905-911 http://www.jstor.org/stable/1549711

Gordon DC Jr, Boudreau PR, Mann KH, Ong JE, Silvert WL, Smith SV, Wattayakorn G, Wulff F, Yanagi T (1996) LOICZ biogeochemical modelling guidelines. LOICZ/R\&S/95-5, VI +96pp. Loicz, texel, The Netherlands ISSN 1383-4304 http://www.ferrybox.eu/imperia/md/content/loicz/print/rsreports/report5.pdf

Gupta GVM, Natesan U, Ramanamurthy MV, Sravan Kumar VG, Viswanathan S, Bhat MS, Ray AK, Subramanian BR (2006) Nutrient budgets for Muthupet lagoon, southeastern India. Curr Sci 90:967-972

Institute of Ocean Management AUC (2003) No impact zone studies in critical habitats: Pulicat lake ecosystem, Integrated Coastal and Marine Area Management (ICMAM) Project Directorate, Government of India; Online report accessed from: http://www.icmam.gov.in/pub.htm

Jayakumar R, Steger K, Chandra TS, Seshadri S (2013) An assessment of temporal variations in physicochemical and microbiological properties of barmouths and lagoons in Chennai (Southeast coast of India). Mar Pollut Bull 70:44-53. https://doi.org/10.1016/j.marpolbul.2013.02.005

Jeppesen E, Søndergaard M, Pedersen AR, Jürgens K, Strzelczak A, Lauridsen TL, Johansson LS (2007) Salinity induced regime shift in shallow brackish lagoons. Ecosystems 10:47-57. https://doi.org/10.1007/s10021-006-9007-6

Kaliyamurthy M (1974) Observations on the environmental characteristics of Pulicat Lake. J Mar Biol Assoc India 16:683-688

Kaur S, Purohit MK (2016) Rainfall statistics of India-2015 (Vol. ESSO/IMD/H). http://hydro.imd.gov.in/hydrometweb. Accessed 30 Aug 2017

Kempe S, Pelger K (1991) Sinks and sources of CO2 in coastal seas: the North Sea. Tellus 43 B:224-235. https://doi.org/10.1034/j.1600-0889.1991.00015.x

Kourzeneva E, Asensio H, Martin E, Faroux S (2012) Global gridded dataset of lake coverage and lake depth for use in numerical weather prediction and climate modelling. Tellus A Dyn Meteorol Oceanogr 64:1-14. https://doi.org/ 10.3402/tellusa.v64i0.15640

Longhurst AR (2007) Ecological geography of the sea, 2nd edn. USA: Academic Press Inc Mishra AK (2016) Monitoring Tamil Nadu flood of 2015 using satellite remote sensing. Nat Hazards 82:1431-1434. https://doi.org/10.1007/s11069-016-2249-5

Mukhopadhyay SK, Biswas H, De TK, Sen S, Jana TK (2002) Seasonal effects on the air-water carbon dioxide exchange in the Hooghly estuary, NE coast of Bay of Bengal, India. J Environ Monit 4:549-552

NASA Landsat Program (2015) Landsat ETM+ scene LC81420512015351LGN01, SLC Off, L1. Sioux Falls: USGS; 2015/12/17

Padma S, Periakali P (1999) Physico-chemical and geochemical studies in Pulicat lake, east coast of India. Indian J Mar Sci 28:434-437

Prasad MBK, Singh G, Ramanathan AL (2016) Nutrient biogeochemistry and net ecosystem metabolism in a tropical coastal mangrove ecosystem. Indian J Geo-Marine Sci 45:1499-1511

Purvaja R, Ramesh R, Shalini A, Rixen T (2008) Biogeochemistry of nitrogen in seagrass and oceanic. Mem Geol Soc India 73:435-460

Radhakrishnan S (1975) Some aspects of the distribution and seasonal abundance of macrophytic flora in a brackish lake, Pulicat, India. In: Aquatic weeds in S. E. Asia. The Hague: Dr. W. Junk b.v., Publishers; pp 107-117

Raju JN, Reddy TVK, Muniratnam P, Gossel W, Wycisk P (2013) Managed aquifer recharge (MAR) by the construction of subsurface dams in the semi-arid regions: a case study of the Kalangi river basin, Andhra Pradesh. J Geol Soc India 82:657-665. https://doi.org/10.1007/s12594-013-0204-6

Raju NJ, Reddy TVK, Munirathnam P (2006) Subsurface dams to harvest rainwater - a case study of the Swarnamukhi River basin, Southern India. Hydrogeol J 14:526-531. https://doi.org/10.1007/s10040-005-0438-5

Raman K, Kaliyamurthy M, Joseph KO (1977) Observations on the ecology and fisheries of the Pulicat lake during drought and normal periods. J mar biol Ass India 19:16-20

Ramasamy SM (2006) Remote sensing and active tectonics of South India. Int J Remote Sens 27:4397-4431. https://doi.org/10.1080/01431160500502603

Ramesh R, Chen Z, Cummins V, Day J, D'Elia C, Dennison B, Forbes DL, Glaser M, Glavovic B, Kremer H, Lange M, Larsen JN, Le Tissier M, Newton A, Pelling M, Purvaja R, Wolanski E (2015) Land-ocean interactions in the coastal zone: past, present \& future. Anthropocene 12:85-98. https://doi.org/10.1016/j. ancene.2016.01.005 
Ramesh R, Purvaja R, Ramesh S, James RA (2002) Historical pollution trends in costal environments of India. Environ Monit Assess 79:151-176. https://doi. org/10.1023/A:1020250717093

Rao NVNDP, Rao PM (1974) Bottom sediments of Pulicat Lake, East Coast of India. Indian J Mar Sci 3:85-92

Reddy SRBC, Jayaraju N, Reddy KRR (2012) Anthropogenic impact on the Pulicat lagoon monitoring with Foraminifera, East coast of India. Mar Sci 2:66-76. https://doi.org/10.5923/j.ms.20120205.05

Sanjeevaraj P J (2006) Macrofauna of Pulicat lake, Chennai: National Biodiversity Authority (NBA) Bulletin 6. Link: http://www.nbaindia.org/uploaded/docs/ bulletin6-pulicatlake.pdf

Sanjeevaraj P J (2011) Management of the food web in Pulicat Lake Ind J Envt Edu 11: 5-16 Link: http://cpreec.org/Indian_Journal_VOL.11_April2011. pdf\#page $=4$

Santhanam, H. (2009) Coupled Biogeochemical and biophysical model for Pulicat lagoon, Ph. D. Thesis, Anna University Chennai, pp. 271

Santhanam H, Amalraj S (2016) Nutrient budgets for Pulicat lagoon using the LOICZ approach. In: ENVIS Special Publication, Lagoons of India, State-of-theart Report, ENVIS Series 2/2015, Centre for Advanced Studies in Marine Biology, Parangipettai, Tamilnadu, sponsored by Ministry of Environment and Forests, Government of India. India: ENVIS CASMB, Parangipettai; pp 7-22

Scheffer M, Carpenter S, Foley J, Folke C, Walker B (2001) Catastrophic shifts in ecosystems. Nature 413:591-596

Shalini A, Ramesh R, Purvaja R, Barnes J (2006) Spatial and temporal distribution of methane in an extensive shallow estuary, south India. J Earth Syst Sci 115: $451-460$

Sprenger C, Parimala Renganayaki S, Schneider M, Elango L (2015) Hydrochemistry and stable isotopes during salinity ingress and refreshment in surface- and groundwater from the Arani-Koratallai (A-K) basin north of Chennai (India). Environ Earth Sci 73:7769-7780. https://doi.org/10.1007/ s12665-014-3269-7

Swaney DP, Hong BH (2009a) The LOICZ budget toolbox documentation. Revision 1. http://nest.su.se/mnode/Toolbox/LOICZ_Toolbox_Documentation.doc

Swaney DP, Hong BH (2009b) The LOICZ budget toolbox. New York: Cornell University; http://nest.su.se/mnode/Toolbox/LOICZ_Toolbox.xls

Van Oldenborgh GJ, Otto FEL, Haustein K, Achutarao K (2016) The heavy precipitation event of December 2015 in Chennai, India. Bull Am Meteorol Soc 97:S87-S91. https://doi.org/10.1175/BAMS-D-16-0129.1

VLIZ (2009) Longhurst biogeographical provinces. In: Longhurst Biogeogr. Prov. Belgium: Flanders Marine Institute.

Winckworth R (1931) Mollusca from Pulicat Lake. J Mollus Stud 19:188-189

Ysebaert T, Herman PMJ, Meire P et al (2003) Large-scale spatial patterns in estuaries: estuarine macrobenthic communities in the Schelde estuary, NW Europe. Estuar Coast Shelf Sci 57:335-355. https://doi.org/10.1016/S0272$7714(02) 00359-1$

\section{Submit your manuscript to a SpringerOpen ${ }^{\circ}$ journal and benefit from:}

- Convenient online submission

- Rigorous peer review

- Open access: articles freely available online

- High visibility within the field

- Retaining the copyright to your article

Submit your next manuscript at $>$ springeropen.com 